\title{
Gold-Catalyzed Addition of $\beta$-Ketoesters to Alkenes: Influence of Electronic and Steric Effects in the Reaction Outcome
}

\author{
Agustina La-Venia, Mirta P. Mischne * and Ernesto G. Mata * (D) \\ Instituto de Química Rosario, Facultad de Ciencias Bioquímicas y Farmacéuticas, Universidad Nacional de \\ Rosario-CONICET, Suipacha 531, Rosario S2002LRK, Argentina; lavenia@iquir-conicet.gov.ar \\ * Correspondence: mischne@iquir-conicet.gov.ar (M.P.M.); mata@iquir-conicet.gov.ar (E.G.M.); \\ Tel.: +54-9-341-4370477 (M.P.M. \& E.G.M.)
}

Received: 7 February 2018; Accepted: 9 March 2018; Published: 10 March 2018

\begin{abstract}
The gold-catalyzed intermolecular hydroalkylation of olefins with $\beta$-ketoesters represents a conceptually attractive and useful synthetic tool; however, it has been scarcely applied, remaining a challenge for chemists. The aim of the current study was to investigate the addition of these 1,3-diketo-compounds to alkenes under gold catalysis conditions, in order to establish the electronic and steric effects of the alkenyl substrates in the reaction outcome. The screening of different catalyst systems and diverse olefins enabled defining the alkenyl requirements and the best reaction conditions to efficiently achieve the coupled products.
\end{abstract}

Keywords: gold catalysis; hydroalkylation; $\beta$-ketoesters; olefins

\section{Introduction}

In recent years, the application of homogeneous gold catalysis has become a very active area of research [1-13]. Gold is considered a "soft" metal, thus it is an excellent carbophilic activator avoiding high oxophilicity, which is exhibited by most of the Lewis acids. Therefore, gold selectively activates unsaturated carbon-carbon bonds (alkynes, alkenes, and allenes) towards nucleophilic attack, catalyzing a large number of organic transformations with high efficiency under a broad scope of reaction conditions (oxygen, water, and alcohols are usually tolerated) [14-19]. The gold-promoted nucleophilic additions onto alkynes and allenes have been widely explored for the generation of both new C-heteroatom ( $\mathrm{N}, \mathrm{S}, \mathrm{O})$ bonds and new carbon-carbon bonds [20-26]. In the last few years, gold-mediated activation of alkenes has been developed as well, but in less extension as expected, due to their lower reactivity comparing with the alkynyl and allenyl counterparts [27-31]. In particular, gold catalysis applied to unactivated olefins presents a limited scope of conditions and reagents, and is mainly referred to heteroatom nucleophilic addition, which, in most of the cases, leads to the formation of heterocyclic structures [32-38]. Indeed, the formation of new carbon-carbon bonds achieved by gold catalysis from alkenyl systems remains scarcely investigated [39-42]. Specifically, the gold-mediated hydroalkylation of olefins using 1,3-dicarbonyl systems, which represents an atom-economic alternative to the classic nucleophilic alkylation, has been barely explored [43-46]. This conceptually attractive synthetic approach presents only a few examples of intermolecular addition of 1,3-diketo-compounds to alkenes, mainly limited to the use of electron-rich alkenes and $\mathrm{Au}(\mathrm{III})$ catalysts $[43,45,47]$.

In this context, we decided to investigate the scope and limitations of gold catalysis for the intermolecular addition of simple $\beta$-ketoesters onto diverse substituted alkenes, attempting to establish the influence of steric and electronic factors on the course of this process. 


\section{Results and Discussion}

As previously exposed, the reported examples of gold catalysis applied to the chemical transformation under study refer to the coupling of 1,3-diketones either with aryl-conjugated alkenes [45] or with electron-rich cyclic alkenes $[43,47]$ in the presence of cationic $\mathrm{Au}(\mathrm{III})$ (Scheme 1a). Particularly interesting are the intramolecular versions of this process that enable the use of alternative dicarbonyl systems, for instance $\beta$-ene-1,3-diketoamides, which afford cyclic lactams (Scheme 1b) [46]. Moreover, in the presence of $(R)$-DTBM-SEGPHOS $(\mathrm{AuCl})_{2}$ and $\mathrm{Cu}(\mathrm{OTf})_{2}$, the asymmetric version of this ene- $\beta$-ketoamide cyclization was achieved (Scheme 1c) [40]. The key modification in this enantioselective hydroalkylation was the use of copper chloride scavengers $[48,49]$.

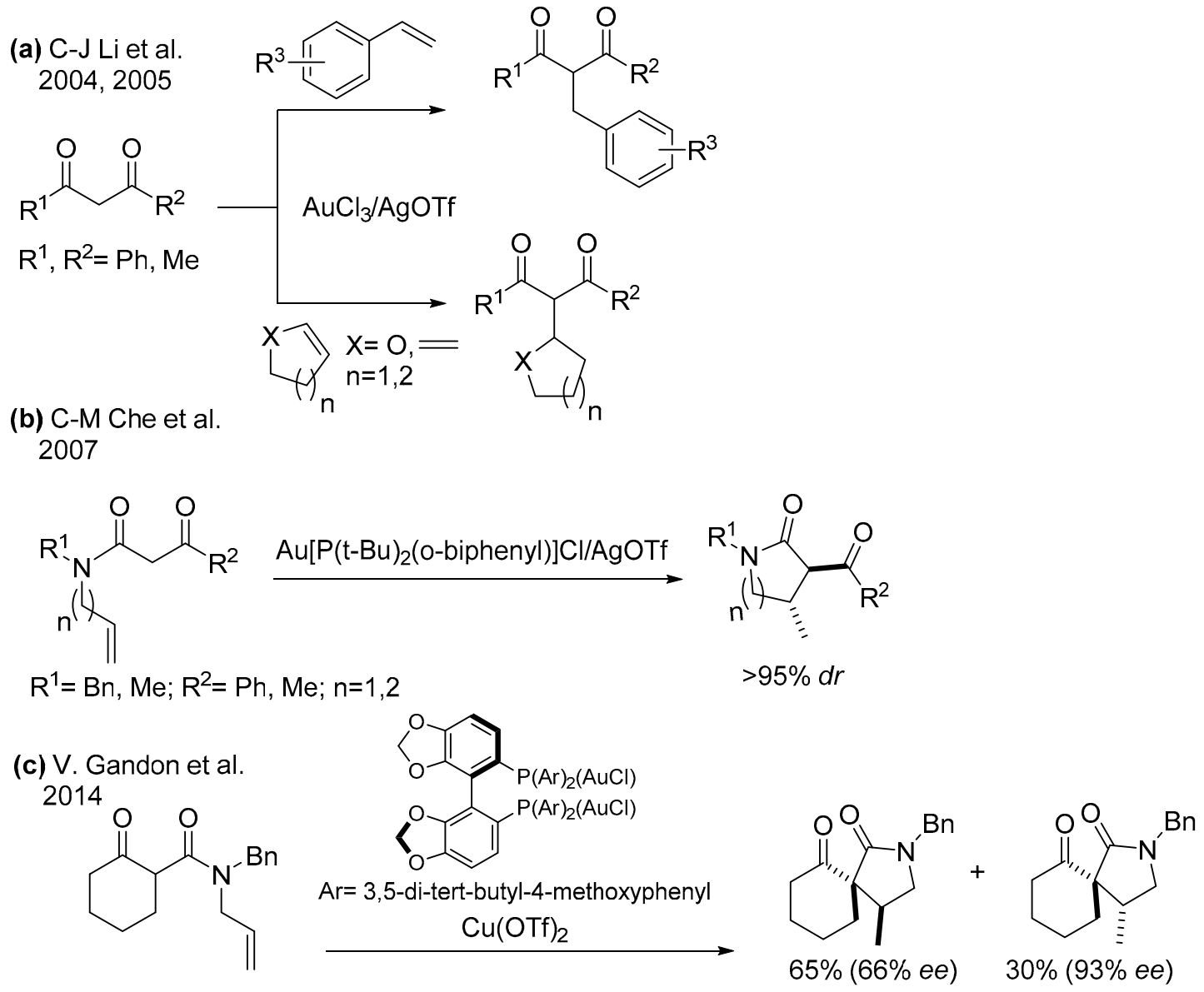

Scheme 1. Gold-catalyzed hydroalkylation of alkenes with 1,3-dicarbonyl compounds.

(a) Intermolecular version with 1,3-diketones. (b) and (c) Intramolecular version with $\beta$-ketoamides.

It is apparent from these reports that the use of $\beta$-ketoesters as the dicarbonyl starting material has been underexplored. In fact, both $\mathrm{Li}$ et al. [45] and Che et al. [46] specifically highlighted that 1,3-dicarbonyl substrates incorporating ester functionalities failed to proceed to the corresponding $\mathrm{C}-\mathrm{C}$ bond formation under gold catalysis, probably due to decomposition of these ester-functionalized starting materials in the presence of high Lewis acidic reagents [45]. In addition, the intramolecular alternative using these kinds of diketo moieties has not been efficiently achieved either. Recently, Gandon and coworkers reported a gold(I)-mediated cyclization via an intramolecular hydroalkylation of an internal diene by a $\beta$-ketoester [44]. However, optimized reaction conditions were accomplished using $\mathrm{Bi}(\mathrm{OTf})_{3} / \mathrm{TfOH}$ as an alternative catalytic system due to the fact that extensive decomposition of starting material was observed using gold catalysts. Some other studies were carried out trying to expand the hydroalkylation of olefins with $\beta$-ketoesters mediated by auric cations; 
however, they were clearly unsuccessful [50]; furthermore, in some conditions, the gold catalysts exhibited an unusual oxophilic behavior [51].

Taking into account this literature review, to achieve our objective, we decided firstly to test the reaction between $\beta$-ketoesters (1a and $\mathbf{1 b}$ ) and $p$-methylstyrene (2a) to obtain the corresponding coupling products $\mathbf{3} \mathbf{a}$ and $\mathbf{3} \mathbf{b}$ (Table 1 ). Different reaction conditions, mainly involving changes in the catalyst mixture and temperature, were evaluated. For ethyl acetoacetate (1a), the use of a $\mathrm{AuCl}_{3} / \mathrm{AgSbF}_{6}$ mixture $(5 \mathrm{~mol} \% / 15 \mathrm{~mol} \%$ ) was the most efficient catalyst system, leading to $3 \mathbf{a}$ in $75 \%$ yield (Entry 1). The product was obtained as an inseparable mixture of two diastereoisomers in a 1:1 ratio, identified and quantified by ${ }^{1} \mathrm{H}-\mathrm{NMR}$ spectra and by HPLC. The use of AgOTf as co-catalyst (Entry 2) provided similar results, whereas the use of $\mathrm{Au}(\mathrm{I})$ catalyst (Entry 3) caused a significant decrease in yield. The addition of $\mathrm{CuCl}_{2}$ to avoid gold reduction resulted in a slight decrease in the reaction yield (Entry 4) [52]. To evaluate the protic triflic acid ( $\mathrm{TfOH})$ effect, this acid was added as the single promoter (Entry 5) [53]. The expected product 3a was obtained but with a notable decreased yield (20\%). Similarly, the use of AgOTf as the only catalyst was also tested, but the reaction did not proceed at all, recovering the starting materials (Entry 6). These latter results proved that auric triflate is the predominant catalytic specie involved in the hydroalkylation under study. On the other hand, changing the dicarbonyl substrate by tert-butyl acetoacetate (1b) gave a complex mixture of unidentified compounds, probably derived from self-condensation of the alkene and $\beta$-ketoester hydrolysis in the acidic media (Entry 7).

Table 1. Gold-catalyzed hydroalkylation of $p$-methylstyrene (2a) with $\beta$-ketoesters $\mathbf{1 a}$ and $\mathbf{1} \mathbf{b}$.

\begin{tabular}{ccccccc} 
\\
\hline 1
\end{tabular}

The reaction was carried out by adding $2 \mathrm{a}$ (1.5 eq.) for $5 \mathrm{~h}$ with a syringe pump to the solution of the $\beta$-ketoesters $\mathbf{1} \mathbf{a}$ or $\mathbf{1 b}$ (1.0 eq.) and catalyst in dichloromethane, then the reaction mixture was stirred overnight. The addition products 3 were eventually isolated and purified by column chromatography. ${ }^{1}$ Yield after column chromatography.

${ }^{2}$ No reaction.

With these optimized conditions in hand, we proceeded to investigate the scope and limitations of the process testing different olefin partners. ${ }^{1} \mathrm{H}-\mathrm{NMR}$ spectroscopic analysis of the crude reaction mixtures showed that, along with the presence of alkylated products 3 and starting materials 1a and 2, signals corresponding to self-condensation olefin polymeric by-products $[54,55]$ could be identified (Table 2). 
Table 2. Evaluation of olefin influence in the $\mathrm{AuCl}_{3} / \mathrm{AgSbF}_{6}-$ promoted hydroalkylation.<smiles>CCOC(=O)CC(C)=O</smiles><smiles>[R][R]1ccc(C(C)C(C(C)=O)C(=O)OCC)cc1</smiles>

Tested alkenes<smiles>[R]c1ccc(C=C)cc1</smiles><smiles>[R]c1ccccc1C=C</smiles><smiles>C=CCc1ccccc1</smiles><smiles>C1=CCCCC1</smiles><smiles>CC=CC(=O)O</smiles>

2a-i 2j,k 21 $2 m$ 2n

\begin{tabular}{|c|c|c|c|c|}
\hline & Alkene & Product $^{1}$ & Recovered Starting Material ${ }^{2}$ & Polymeric by-Products ${ }^{3}$ \\
\hline 1 & $2 \mathbf{a}, R^{2}=p-\mathrm{Me}$ & $3 a, 75 \%$ & 1a & Yes \\
\hline 2 & $2 \mathbf{b}, R^{2}=p-\mathrm{Et}$ & $3 b, 50 \%$ & 1a & Yes \\
\hline 3 & $2 \mathrm{c}, R^{2}=p-t \mathrm{Bu}$ & $3 \mathbf{c}, 20 \%$ & 1a & Yes \\
\hline 4 & $2 \mathrm{~d}, \mathrm{R}^{2}=p-\mathrm{CH}_{2} \mathrm{Cl}$ & $3 d, 10 \%(35 \%)^{4}$ & 1a & Yes \\
\hline 5 & $2 \mathbf{e}, R^{2}=p$-OAc & $3 \mathbf{e}$, traces & 1a & Yes \\
\hline 6 & $2 \mathrm{f}, R^{2}=p$-OMe & $3 f, 7 \%(25 \%)^{4}$ & 1a & Yes \\
\hline 7 & $2 \mathrm{~g}, R^{2}=p-\mathrm{O} t \mathrm{Bu}$ & $3 g$, traces & $1 a$ & No \\
\hline 8 & $2 \mathbf{h}, R^{2}=p-\mathrm{CO}_{2} \mathrm{Me}$ & NP & $1 a+2 h$ & No \\
\hline 9 & $2 \mathbf{i}, R^{2}=p-\mathrm{Br}$ & NP & $1 a+2 i$ & No \\
\hline 10 & $2 \mathbf{j}, R^{2}=o-\mathrm{Br}$ & NP & $1 a+2 j$ & No \\
\hline 11 & $2 \mathbf{k}, R^{2}=o-\mathrm{Me}$ & NP & $1 a+2 k$ & Yes \\
\hline 12 & 21 & NP & $1 a+21$ & No \\
\hline 13 & $2 m$ & NP & $1 a^{5}$ & No \\
\hline 14 & $2 n$ & NP & $1 a+2 n$ & No \\
\hline
\end{tabular}

1 Yields correspond to final products purified by flash column chromatography. The addition products 3 were generated as inseparable mixtures of diastereoisomers in 1:1 ratio (see Supplementary Materials). NP: No addition product 3 was observed. ${ }^{2}$ Starting material remained in the reaction mixtures. ${ }^{3}$ Signals attributed to polymeric by-products were observed by ${ }^{1} \mathrm{H}-\mathrm{NMR}$ spectra of the reaction mixtures. ${ }^{4}$ Optimized conditions: $\mathrm{AuCl}_{3} / \mathrm{AgOTf}$ $(5 / 15 \mathrm{~mol} \%), 0{ }^{\circ} \mathrm{C} .{ }^{5} \mathbf{1 a}$ was partially hydrolyzed, $\mathbf{2 m}$ was evaporated during the work up of the reaction.

A detailed examination of the results indicates that the reaction under study is very sensitive to structural and electronic features of the alkene. In the case of para-substituted styrene derivatives (2a-i), the best results have been achieved for those substrates having both weak electron-donating such as alkyl groups (2a-c, Entries 1-3) and weak electro-withdrawing substituents (2d, Entry 4), leading to the adducts $3 \mathbf{a}-\mathbf{d}$ up to $75 \%$ yield. In the case of other aromatic substrates with stronger electron-donating groups $(\mathbf{2} \mathbf{e}-\mathbf{g})$, the corresponding products were detected but with considerable decrease in the yields and along with large amounts of polymeric material (Entries 5 and 6), except for $2 \mathbf{g}$ (Entry 7 ). These results revealed an efficient gold-promoted alkene-activation, except for the most bulky substituted styrene $\left(R^{2}=\mathrm{O} t \mathrm{Bu}\right)$; however, unfortunately, the polymerization process was predominant. Interestingly, those substrates with strong electron-withdrawing substituents $\left(2 \mathbf{h}, R^{2}=\mathrm{CO}_{2} \mathrm{Me}\right.$ and $\mathbf{2 i}$, $R^{2}=\mathrm{Br}$, Entries 8 and 9) did not provide the desired products and neither the possible products of polymerization, recovering both starting materials, which could be justified by an ineffective olefin coordination with the metal. A similar tendency was observed for ortho-substituted styrene derivatives $\mathbf{2} \mathbf{j}$ and $\mathbf{2 k}$, which did not generate the desired addition products, regardless of their electronic properties, recovering in both cases the unreacted starting materials (Entries 10 and 11). Though, in the case of alkene 2k (Entry 11), a small amount of polymerization product was observed, demonstrating a poor activation of the olefin by the $\mathrm{Au}(\mathrm{III})$ [56,57], probably due to steric hindrance of the substituent in ortho position in comparison to the para analogue 2a. As expected, the non-aromatic alkenes or alkenes structurally different to styrene, remained unchanged under the optimized conditions (Entries 12-14), which clearly indicated that the cationic gold failed to promote their activation. 
Taking into account these results, we can remark about two major difficulties for the broad application of this synthetic tool. According to the most commonly proposed mechanism based on the cationic gold activation of alkene species followed by methylene nucleophilic attack, the first difficulty is related to the activation of alkenes by coordination with the active gold species. In order to achieve such gold coordination, olefins must present sufficient electron density, restricting the type of alkene able to participate in the hydroalkylation. This limitation becomes evident in those alkenes with low electron density, which remained unreacted in the presence of the auric cation $(\mathbf{2} \mathbf{h}-\mathbf{j}$ and $\mathbf{2} \mathbf{l}-\mathbf{n})$.

The second drawback of the reaction arises from competition with the self-addition of the olefins. Electron rich olefin can coordinate with the cationic gold, but the presence of free unactivated olefin in the reaction medium can also efficiently act as a nucleophile. Thus, self-addition occurs between the metal-coordinated olefin (electrophilic) and the free olefin (nucleophilic), generating the polymeric by-product. There is a competition between both potential nucleophiles, high-electron density olefins and the corresponding enol of 1,3-dicarbonyl compounds. The nucleophilic enolate can be generated by the presence of metal co-catalyst, such as $\mathrm{Cu}$ or can be present directly in the dicarbonyl equilibrium. In the case of $\beta$-ketoesters, only a small proportion is present as the enol form (8\% in DCM) [58]; therefore, high electron density olefins are better nucleophiles, generating mainly polymerization products during catalysis. In contrast, reactions involving diketones instead of $\beta$-ketoesters are more efficient for the hydroalkylation of alkenes since these diketo compounds are mostly in their enol form (81\% in DCM).

Under these premises, we carried out further screening conditions to some promising substrates ( $2 \mathbf{e}$ and $\mathbf{2 f}$ ). It can be assumed that reduction of olefin self-addition would increase the efficiency of the hydroalkylation reaction. To achieve the limitation of this undesired reaction, various strategies were tested. The first attempts that involved the incorporation of base to the reaction mixture in order to shift the keto/enol equilibrium did not proceed as expected. For instance, the addition of $t \mathrm{BuOK}$ led to a slight increase of coupling while amine bases poisoned the catalyst. Fortunately, slow alkene addition at low temperature showed promising effects. Moreover, when the decrease in temperature was combined with a simple exchange of co-catalyst (AgOTf instead of $\left.\mathrm{AgSbF}_{6}\right)$, 3f was obtained with a considerably higher yield (25\%) (Entry 6, Table 2). Similar results were observed for substrate $2 \mathrm{~d}$ $\left(R^{2}=\mathrm{CH}_{2} \mathrm{Cl}\right)$, affording $3 \mathbf{d}$ with a $35 \%$ yield (Entry 4 , Table 2$)$.

\section{Materials and Methods}

\subsection{General Information}

Chemical reagents were purchased from commercial suppliers and used without further purification, unless otherwise noted. Solvents were analytical grade or were purified by standard procedures prior to use. Reactions requiring inert atmosphere were carried out under a high-purity dry nitrogen atmosphere. Solvents from these reactions were transferred with syringe under high-purity dry nitrogen pressure. Yields were calculated for material judged homogeneous by thin layer chromatography (TLC) and nuclear magnetic resonance $\left({ }^{1} \mathrm{H}-\mathrm{NMR}\right)$. All reactions were monitored by thin layer chromatography performed on silica gel 60 F254 pre-coated aluminum sheets, visualized by a $254 \mathrm{~nm}$ UV lamp, and stained with an ethanolic solution of 4-anisaldehyde. Column flash chromatography was performed using silica gel 60 (230-400 mesh).

\subsection{Instrumental and Physical Data}

1H-NMR spectra were recorded in a Bruker Avance spectrometer (Bruker Analytik GmbH, Karlsruhe, Germany) at $300 \mathrm{MHz}$, in $\mathrm{CDCl}_{3}$ with tetramethylsilane (TMS) as internal standard (0 ppm). ${ }^{13} \mathrm{C}-\mathrm{NMR}$ spectra were recorded on the same apparatus at $75 \mathrm{MHz}$ with $\mathrm{CDCl}_{3}$ as solvent and reference $(76.9 \mathrm{ppm})$. Chemical shifts $(\delta)$ are reported in ppm upfield from TMS and coupling constants $(J)$ are expressed in Hertz. The following abbreviations are used to indicate the multiplicities: $\mathrm{s}=$ singlet, $\mathrm{d}=$ doublet, $\mathrm{t}=$ triplet, $\mathrm{q}=$ quartet, $\mathrm{m}=$ multiplet, $\mathrm{bs}=$ broad singlet. 
IR spectra were obtained using a Shimadzu, Prestige-21 FT-IR spectrometer (Shimadzu, Kioto, Japan), wavelengths are informed in $\mathrm{cm}^{-1}$, and only partial spectral data are listed.

High resolution mass spectra (HRMS) were recorded on a Bruker micrOTOF-Q II spectrometer obtained on a Q-TOF mass spectrometer and detection of the ions was performed in electrospray ionization, positive ion mode.

\subsection{Synthetic Procedures}

Gold-catalyzed hydroalkylation: A mixture of $\mathrm{AuCl}_{3}(15.2 \mathrm{mg}, 0.05 \mathrm{mmol}, 5 \mathrm{~mol} \%)$ and $\mathrm{AgSbF}_{6}$ ( $51.5 \mathrm{mg}, 0.15 \mathrm{mmol}, 15 \mathrm{~mol} \%$ ) in anhydrous DCM ( $2 \mathrm{~mL})$ under $\mathrm{N}_{2}$ atmosphere was stirred at room temperature for $2 \mathrm{~h}$. The $\beta$-ketoester, ethyl acetoacetate $1 \mathrm{a},(0.13 \mathrm{~mL}, 1 \mathrm{mmol})$ was then added to the catalysts solution previously formed, followed by the addition of the solution of the corresponding alkene 2 ( $1.5 \mathrm{mmol}, 1.5$ eq.) in anhydrous DCM $(3 \mathrm{~mL})$ with a syringe-pump during $5 \mathrm{~h}$ at room temperature or at $0{ }^{\circ} \mathrm{C}$. The reaction mixture was further stirred at room temperature overnight under $\mathrm{N}_{2}$ atmosphere. After that time, the solvent was evaporated and the reaction crude was purified by column chromatography on silica gel (eluent: Hexane-AcOEt with increasing polarity) to afford addition products 3 (1:1 diastereoisomeric mixture). Note: the $\mathrm{AuCl}_{3}$ catalyst must be weighed under a nitrogen cone because of its high hygroscopicity.

\subsection{Analytical Data of Individual Compounds}

Ethyl 2-acetyl-3-(p-tolyl)butanoate 3a. Yield: $75 \%$ of colorless oil (inseparable mixture with diastereoisomeric ratio 1:1). IR (Film) $\left(\mathrm{cm}^{-1}\right)$ : 2964, 2932, 1743 ( $(\mathrm{CO}), 1717$ ( $(\mathrm{CO}), 1513,1177 .{ }^{1} \mathrm{H}-\mathrm{NMR}$ $\left(\mathrm{CDCl}_{3}, 300 \mathrm{MHz}\right): \delta 7.09(8 \mathrm{H}, \mathrm{bs}, \mathrm{ArH}), 4.22\left(2 \mathrm{H}, \mathrm{q}, J=7.2 \mathrm{~Hz},-\mathrm{OCH}_{2} \mathrm{CH}_{3}\right), 3.90(2 \mathrm{H}, \mathrm{q}, J=7.1 \mathrm{~Hz}$, $\left.-\mathrm{OCH}_{2} \mathrm{CH}_{3}\right), 3.76(1 \mathrm{H}, \mathrm{d}, J=11.0 \mathrm{~Hz}, \mathrm{H}-2), 3.71(1 \mathrm{H}, \mathrm{d}, J=10.9 \mathrm{~Hz}, \mathrm{H}-2), 3.56-3.45\left(2 \mathrm{H}, \mathrm{m}, \mathrm{H}-1^{\prime}\right), 2.30(6 \mathrm{H}$, $\left.\mathrm{s}, \mathrm{ArCH}_{3}\right)^{*}, 2.29(3 \mathrm{H}, \mathrm{s}, \mathrm{H}-4)^{*}, 1.94(3 \mathrm{H}, \mathrm{s}, \mathrm{H}-4)^{*}, 1.31-1.27\left(6 \mathrm{H}, \mathrm{m}, \mathrm{H}-2^{\prime}\right.$ and $\left.-\mathrm{OCH}_{2} \mathrm{CH}_{3}\right), 1.21(3 \mathrm{H}$,

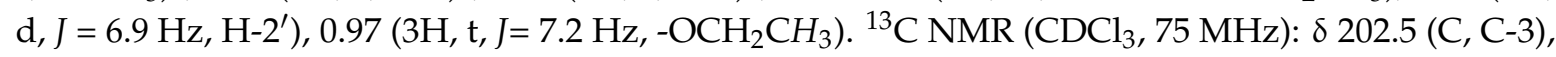
202.4 (C, C-3), 168.6 (C, C-1), 168.1 (C, C-1), 140.1 (C, Ar), 139.9 (C, Ar), 136.4 (C, Ar), 136.2 (C, Ar), $129.3(2 \mathrm{CH}, \mathrm{Ar}), 129.0(2 \mathrm{CH}, \mathrm{Ar}), 127.2(2 \mathrm{CH}, \mathrm{Ar}), 127.1$ (2 CH, Ar), $67.6(\mathrm{CH}, \mathrm{C}-2), 67.1(\mathrm{CH}, \mathrm{C}-2)$, $61.3\left(\mathrm{CH}_{2},-\mathrm{OCH}_{2} \mathrm{CH}_{3}\right), 61.0\left(\mathrm{CH}_{2},-\mathrm{OCH}_{2} \mathrm{CH}_{3}\right), 39.6\left(\mathrm{CH}, \mathrm{C}-1^{\prime}\right), 39.3\left(\mathrm{CH}, \mathrm{C}-1^{\prime}\right), 29.7\left(\mathrm{CH}_{3}, \mathrm{C}-4\right)$, $29.4\left(\mathrm{CH}_{3}, \mathrm{C}-4\right), 20.9\left(2 \mathrm{CH}_{3}, \mathrm{Ar}-\mathrm{CH}_{3}\right), 20.6\left(\mathrm{CH}_{3}, \mathrm{C}-2^{\prime}\right), 20.3\left(\mathrm{CH}_{3}, \mathrm{C}-2\right), 14.0\left(\mathrm{CH}_{3},-\mathrm{OCH}_{2} \mathrm{CH}_{3}\right)$, 13.6 $\left(\mathrm{CH}_{3},-\mathrm{OCH}_{2} \mathrm{CH}_{3}\right)$. HRMS (ESI) $m / z$ calcd. for $\mathrm{C}_{15} \mathrm{H}_{20} \mathrm{NaO}_{3}[\mathrm{M}+\mathrm{Na}]^{+}$271.1305, found 271.1302.

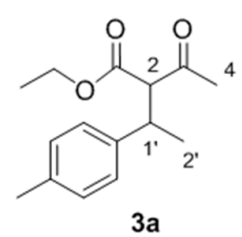

Ethyl 2-acetyl-3-(4-ethylphenyl)butanoate $3 \mathbf{b}$. Yield: 50\% of colorless oil (inseparable mixture with diastereoisomeric ratio 1:1). IR (Film) $\left(\mathrm{cm}^{-1}\right)$ : 2965, 2932, 2873, 1744 ( $(\mathrm{CO}), 1716(v C O), 1513,1176$. ${ }^{1} \mathrm{H}-\mathrm{NMR}\left(\mathrm{CDCl}_{3}, 300 \mathrm{MHz}\right): \delta 7.11(8 \mathrm{H}, \mathrm{bs}, \mathrm{ArH}), 4.22\left(2 \mathrm{H}, \mathrm{q}, J=7.2 \mathrm{~Hz},-\mathrm{OCH}_{2} \mathrm{CH}_{3}\right), 3.89(2 \mathrm{H}, \mathrm{q}$, $\left.J=7.1 \mathrm{~Hz},-\mathrm{OCH}_{2} \mathrm{CH}_{3}\right), 3.77(1 \mathrm{H}, \mathrm{d}, J=11.0 \mathrm{~Hz}, \mathrm{H}-2), 3.71(1 \mathrm{H}, \mathrm{d}, J=11.0 \mathrm{~Hz}, \mathrm{H}-2), 3.59-3.46(2 \mathrm{H}, \mathrm{m}$, $\left.\mathrm{H}-1^{\prime}\right), 2.60\left(4 \mathrm{H}, \mathrm{q}, J=7.5 \mathrm{~Hz}, \mathrm{H}-1^{\prime \prime}\right), 2.29(3 \mathrm{H}, \mathrm{s}, \mathrm{H}-4), 1.93(3 \mathrm{H}, \mathrm{s}, \mathrm{H}-4), 1.31-1.17\left(15 \mathrm{H}, \mathrm{m}, \mathrm{H}-2^{\prime}, \mathrm{H}-2^{\prime \prime}\right.$ and $\left.-\mathrm{OCH}_{2} \mathrm{CH}_{3}\right)^{*}, 0.94\left(3 \mathrm{H}, \mathrm{t}, J=7.1 \mathrm{~Hz}, \mathrm{H}-2^{\prime \prime}\right) *{ }^{13} \mathrm{C} \mathrm{NMR}\left(\mathrm{CDCl}_{3}, 75 \mathrm{MHz}\right): \delta 202.5(2 \mathrm{C}, \mathrm{C}-3), 168.5(\mathrm{C}, \mathrm{C}-1)$, 168.1 (C, C-1), 142.6 (2 C, Ar), 140.2 (C, Ar), 140.1 (C, Ar), 128.0 (2 CH, Ar), 127.7 (2 CH, Ar), $127.2(2 \mathrm{CH}$, $\mathrm{Ar}), 127.1(2 \mathrm{CH}, \mathrm{Ar}), 67.6(\mathrm{CH}, \mathrm{C}-2), 67.0(\mathrm{CH}, \mathrm{C}-2), 61.3\left(\mathrm{CH}_{2},-\mathrm{OCH}_{2} \mathrm{CH}_{3}\right), 60.9\left(\mathrm{CH}_{2},-\mathrm{OCH}_{2} \mathrm{CH}_{3}\right)$, $39.6\left(\mathrm{CH}, \mathrm{C}-1^{\prime}\right), 39.3\left(\mathrm{CH}, \mathrm{C}-1^{\prime}\right), 29.7\left(\mathrm{CH}_{3}, \mathrm{C}-4\right), 29.3\left(\mathrm{CH}_{3}, \mathrm{C}-4\right), 28.3\left(\mathrm{CH}_{2}, \mathrm{C}-1^{\prime \prime}\right), 28.2\left(\mathrm{CH}_{2}, \mathrm{C}-1^{\prime \prime}\right)$, $20.5\left(\mathrm{CH}_{3}, \mathrm{C}-2^{\prime}\right)^{*}, 20.2\left(\mathrm{CH}_{3}, \mathrm{C}-2^{\prime}\right)^{*}, 15.4\left(\mathrm{CH}_{3}, \mathrm{C}-2^{\prime \prime}\right)^{*}, 15.3\left(\mathrm{CH}_{3}, \mathrm{C}-2^{\prime \prime}\right)^{*}, 14.0\left(\mathrm{CH}_{3},-\mathrm{OCH}_{2} \mathrm{CH}_{3}\right)$, 13.6 $\left(\mathrm{CH}_{3},-\mathrm{OCH}_{2} \mathrm{CH}_{3}\right)$. HRMS (ESI) $m / z$ calcd. for $\mathrm{C}_{16} \mathrm{H}_{23} \mathrm{NaO}_{3}[\mathrm{M}+\mathrm{Na}]^{+} 285.1461$, found 285.1461. 


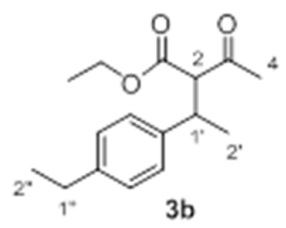

Ethyl 2-acetyl-3-(4-(tert-butyl)phenyl)butanoate 3c Yield: 20\% of colorless oil (inseparable mixture with diastereoisomeric ratio 1:1). ${ }^{1} \mathrm{H}-\mathrm{NMR}\left(\mathrm{CDCl}_{3}, 300 \mathrm{MHz}\right): \delta 7.29(4 \mathrm{H}, \mathrm{d}, J=8.5 \mathrm{~Hz}, \mathrm{ArH}), 7.15-7.10(4 \mathrm{H}$, $\mathrm{m}, \mathrm{ArH}), 4.22\left(2 \mathrm{H}, \mathrm{q}, J=7.1 \mathrm{~Hz},-\mathrm{OCH}_{2} \mathrm{CH}_{3}\right), 3.93-3.83\left(2 \mathrm{H}, \mathrm{m},-\mathrm{OCH}_{2} \mathrm{CH}_{3}\right), 3.77(1 \mathrm{H}, \mathrm{d}, J=10.9 \mathrm{~Hz}$, $\mathrm{H}-2), 3.70(1 \mathrm{H}, \mathrm{d}, J=11.0 \mathrm{~Hz}, \mathrm{H}-2), 3.57-3.48\left(2 \mathrm{H}, \mathrm{m}, \mathrm{H}-\mathrm{1}^{\prime}\right), 2.30(3 \mathrm{H}, \mathrm{s}, \mathrm{H}-4), 1.93(3 \mathrm{H}, \mathrm{s}, \mathrm{H}-4), 1.34-1.22$ $\left(27 \mathrm{H}, \mathrm{m}, \mathrm{H}-2^{\prime},-\mathrm{C}\left(\mathrm{CH}_{3}\right)_{3} \text { and }-\mathrm{OCH}_{2} \mathrm{CH}_{3}\right)^{*}, 0.88\left(3 \mathrm{H}, \mathrm{t}, J=7,1 \mathrm{~Hz},-\mathrm{OCH}_{2} \mathrm{CH}_{3}\right)^{*} .{ }^{13} \mathrm{C} \mathrm{NMR}\left(\mathrm{CDCl}_{3}\right.$, 75 MHz): $\delta 202.5$ (2 C, C-3), 168.6 (C, C-1), 168.5 (C, C-1); 149.6 (C, Ar); 149.5 (C, Ar); 139.9 (C, Ar); 139.8 (C, Ar); 127.0 (2 CH, Ar); 126.8 (2 CH, Ar); 125.4 (2 CH, Ar); 125.1 (2 CH, Ar); 67.7 (CH, C-2); $67.0(\mathrm{CH}, \mathrm{C}-2) ; 61.3\left(\mathrm{CH}_{2},-\mathrm{OCH}_{2} \mathrm{CH}_{3}\right) ; 60.9\left(\mathrm{CH}_{2},-\mathrm{OCH}_{2} \mathrm{CH}_{3}\right) ; 39.5\left(\mathrm{CH}, \mathrm{C}-1^{\prime}\right) ; 39.3\left(\mathrm{CH}, \mathrm{C}-1^{\prime}\right) ; 34.3(2 \mathrm{C}$, $\left.-\mathrm{C}\left(\mathrm{CH}_{3}\right)_{3}\right) ; 31.2\left(6 \mathrm{CH}_{3},-\mathrm{C}\left(\mathrm{CH}_{3}\right)_{3}\right) ; 29.7\left(\mathrm{CH}_{3}, \mathrm{C}-4\right) ; 29.3\left(\mathrm{CH}_{3}, \mathrm{C}-4\right) ; 20.5\left(\mathrm{CH}_{3}, \mathrm{C}-2^{\prime}\right) ; 20.1\left(\mathrm{CH}_{3}, \mathrm{C}-2^{\prime}\right)$; $14.0\left(\mathrm{CH}_{3},-\mathrm{OCH}_{2} \mathrm{CH}_{3}\right) ; 13.5\left(\mathrm{CH}_{3},-\mathrm{OCH}_{2} \mathrm{CH}_{3}\right)$. HRMS (ESI) $\mathrm{m} / z$ calcd. for $\mathrm{C}_{18} \mathrm{H}_{30} \mathrm{NO}_{3}\left[\mathrm{M}+\mathrm{NH}_{4}\right]^{+}$ 308.2226, found 308.2218.

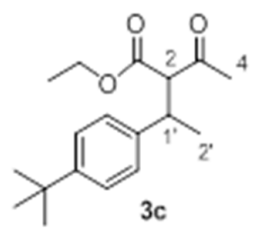

Ethyl 2-acetyl-3-(4-(chloromethyl)phenyl)butanoate 3d Yield: 35\% of colorless oil (inseparable mixture with diastereoisomeric ratio 1:1). ${ }^{1} \mathrm{H}-\mathrm{NMR}\left(\mathrm{CDCl}_{3}, 300 \mathrm{MHz}\right): \delta 7.31(4 \mathrm{H}, \mathrm{d}, J=7.5 \mathrm{~Hz}, \mathrm{ArH}), 7.23-7.18(4 \mathrm{H}$, $\mathrm{m}, \mathrm{ArH}), 4.55\left(4 \mathrm{H}, \mathrm{bs},-\mathrm{CH}_{2} \mathrm{Cl}\right), 4.23\left(2 \mathrm{H}, \mathrm{q}, J=7.1 \mathrm{~Hz},-\mathrm{OCH}_{2} \mathrm{CH}_{3}\right), 3.89\left(2 \mathrm{H}, \mathrm{q}, J=7.1 \mathrm{~Hz},-\mathrm{OCH}_{2} \mathrm{CH}_{3}\right)$, $3.78(1 \mathrm{H}, \mathrm{d}, J=10.8 \mathrm{~Hz}, \mathrm{H}-2), 3.73(1 \mathrm{H}, \mathrm{d}, J=10.9 \mathrm{~Hz}, \mathrm{H}-2), 3.61-3.50\left(2 \mathrm{H}, \mathrm{m}, \mathrm{H}-1^{\prime}\right), 2.30(3 \mathrm{H}, \mathrm{s}, \mathrm{H}-4)$, $1.96(3 \mathrm{H}, \mathrm{s}, \mathrm{H}-4), 1.31-1.27\left(6 \mathrm{H}, \mathrm{m}, \mathrm{H}-2^{\prime}\right.$ and $\left.-\mathrm{OCH}_{2} \mathrm{CH}_{3}\right), 1.23\left(3 \mathrm{H}, \mathrm{d}, J=6.9 \mathrm{~Hz}, \mathrm{H}-2^{\prime}\right), 0.95(3 \mathrm{H}, \mathrm{t}$, $\left.J=7,1 \mathrm{~Hz},-\mathrm{OCH}_{2} \mathrm{CH}_{3}\right) .{ }^{13} \mathrm{C}$ NMR $\left(\mathrm{CDCl}_{3}, 75 \mathrm{MHz}\right): \delta 202.0$ (C, C-3), 201.9 (C, C-3), 168.3 (C, C-1), 167.9 (C, C-1), 143.5 (C, Ar), 143.4 (C, Ar), 135.9 (2 C, Ar), 128.8 (2 CH, Ar), 128.6 (2 CH, Ar), 127.7 (2 CH, $\mathrm{Ar}), 127.6(2 \mathrm{CH}, \mathrm{Ar}), 67.2(\mathrm{CH}, \mathrm{C}-2), 66.8(\mathrm{CH}, \mathrm{C}-2), 61.4\left(\mathrm{CH}_{2},-\mathrm{OCH}_{2} \mathrm{CH}_{3}\right), 61.1\left(\mathrm{CH}_{2},-\mathrm{OCH}_{2} \mathrm{CH}_{3}\right)$, $45.8\left(\mathrm{CH}_{2},-\mathrm{CH}_{2} \mathrm{Cl}\right), 45.7\left(\mathrm{CH}_{2},-\mathrm{CH}_{2} \mathrm{Cl}\right), 39.4\left(\mathrm{CH}, \mathrm{C}-1^{\prime}\right), 39.3\left(\mathrm{CH}, \mathrm{C}-1^{\prime}\right), 29.7\left(\mathrm{CH}_{3}, \mathrm{C}-4\right), 29.4\left(\mathrm{CH}_{3}\right.$, $\mathrm{C}-4), 20.3\left(\mathrm{CH}_{3}, \mathrm{C}-2^{\prime}\right), 20.2\left(\mathrm{CH}_{3}, \mathrm{C}-2^{\prime}\right), 14.0\left(\mathrm{CH}_{3},-\mathrm{OCH}_{2} \mathrm{CH}_{3}\right), 13.6\left(\mathrm{CH}_{3},-\mathrm{OCH}_{2} \mathrm{CH}_{3}\right)$. HRMS (ESI) $m / z$ calcd. for $\mathrm{C}_{15} \mathrm{H}_{23} \mathrm{ClNO}_{3}\left[\mathrm{M}+\mathrm{NH}_{4}\right]^{+}$300.1366, found 300.1358.

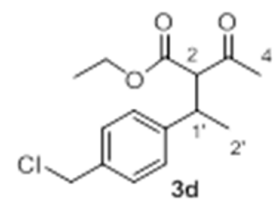

Ethyl 2-acetyl-3-(4-methoxyphenyl)butanoate 3f Yield: 25\% of colorless oil (inseparable mixture with diastereoisomeric ratio 1:1). ${ }^{1} \mathrm{H}-\mathrm{NMR}\left(\mathrm{CDCl}_{3}, 300 \mathrm{MHz}\right): \delta 7.14(2 \mathrm{H}, \mathrm{d}, J=6.0 \mathrm{~Hz}, \mathrm{ArH}), 7.11(2 \mathrm{H}, \mathrm{d}$, $J=6.0 \mathrm{~Hz}, \mathrm{ArH}), 6.82(4 \mathrm{H}, \mathrm{dd}, J=8.7,0.9 \mathrm{~Hz}, \mathrm{ArH}), 4.21\left(2 \mathrm{H}, \mathrm{q}, J=7.2 \mathrm{~Hz},-\mathrm{OCH}_{2} \mathrm{CH}_{3}\right), 3.90(2 \mathrm{H}, \mathrm{q}$, $\left.J=7.2 \mathrm{~Hz},-\mathrm{OCH}_{2} \mathrm{CH}_{3}\right), 3.77\left(6 \mathrm{H}, \mathrm{s},-\mathrm{OCH}_{3}\right), 3.74(1 \mathrm{H}, \mathrm{d}, J=11.1 \mathrm{~Hz}, \mathrm{H}-2), 3.68(1 \mathrm{H}, \mathrm{d}, J=11.1 \mathrm{~Hz}$, $\mathrm{H}-2)$, 3.55-3.44 (2H, m, H-1' $), 2.29(3 \mathrm{H}, \mathrm{s}, \mathrm{H}-4), 1.93(3 \mathrm{H}, \mathrm{s}, \mathrm{H}-4), 1.31-1.26\left(6 \mathrm{H}, \mathrm{m}, \mathrm{H}-2^{\prime}\right.$ and $\left.-\mathrm{OCH}_{2} \mathrm{CH}_{3}\right)$, $1.21\left(3 \mathrm{H}, \mathrm{d}, J=6.9 \mathrm{~Hz}, \mathrm{H}-2^{\prime}\right), 0.98\left(3 \mathrm{H}, \mathrm{t}, J=7.2 \mathrm{~Hz},-\mathrm{OCH}_{2} \mathrm{CH}_{3}\right) .{ }^{13} \mathrm{C} \mathrm{NMR}\left(\mathrm{CDCl}_{3}, 75 \mathrm{MHz}\right): \delta 202.5(\mathrm{C}$, C-3), 202.4 (C, C-3), 168.6 (C, C-1), 168.1 (C, C-1), 158.2 (2 C, Ar), 135.2 (C, Ar), 134.9 (C, Ar), 128.2 (4 CH, $\mathrm{Ar}), 113.9(2 \mathrm{CH}, \mathrm{Ar}), 113.6(2 \mathrm{CH}, \mathrm{Ar}), 67.7(\mathrm{CH}, \mathrm{C}-2), 67.1(\mathrm{CH}, \mathrm{C}-2), 61.3\left(\mathrm{CH}_{2},-\mathrm{OCH}_{2} \mathrm{CH}_{3}\right), 61.0\left(\mathrm{CH}_{2}\right.$, $\left.-\mathrm{OCH}_{2} \mathrm{CH}_{3}\right), 55.1\left(\mathrm{CH}_{3},-\mathrm{OCH}_{3}\right), 55.0\left(\mathrm{CH}_{3},-\mathrm{OCH}_{3}\right), 39.2\left(\mathrm{CH}, \mathrm{C}-1^{\prime}\right), 38.9\left(\mathrm{CH}, \mathrm{C}-1^{\prime}\right), 29.7\left(\mathrm{CH}_{3}, \mathrm{C}-4\right)$, 
$29.3\left(\mathrm{CH}_{3}, \mathrm{C}-4\right), 20.6\left(\mathrm{CH}_{3}, \mathrm{C}-2^{\prime}\right), 20.3\left(\mathrm{CH}_{3}, \mathrm{C}-2^{\prime}\right), 14.0\left(\mathrm{CH}_{3},-\mathrm{OCH}_{2} \mathrm{CH}_{3}\right), 13.6\left(\mathrm{CH}_{3},-\mathrm{OCH}_{2} \mathrm{CH}_{3}\right)$. HRMS (ESI) $m / z$ calcd. for $\mathrm{C}_{15} \mathrm{H}_{24} \mathrm{NO}_{4}\left[\mathrm{M}+\mathrm{NH}_{4}\right]^{+} 282.1705$, found 282.1694 .

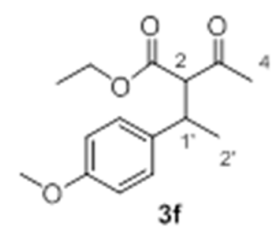

\section{Conclusions}

In conclusion, this study demonstrates that the intermolecular hydroalkylation of alkenes with $\beta$-ketoesters catalyzed by cationic gold species can be achieved efficiently by selecting the substrate patterns. It is worthwhile to highlight that, in most of the cases, the $\beta$-ketoester substrate (ethylacetoacetate 1a) exhibited a significant stability to gold catalysis conditions, and only under certain conditions (high temperature, addition of extra acid to the reaction mixture) did its hydrolysis took place. Regarding the alkene requirements, it is concluded that the coupling reaction proceeds efficiently only with those olefinic structures whose electron density is enough to coordinate with the cationic gold species but not too elevated to exhibit predominant nucleophilic character that would lead to the self-addition as the main reaction and, therefore, prevent the reaction with the nucleophilic 1,3-dicarbonyl moiety of the $\beta$-ketoester. These requirements limit the scope of suitable alkenes for this synthetic tool. In order to improve yields, low temperature during a very slow addition of the olefin was successfully carried out.

Supplementary Materials: The following are available online, Figures S1-4: ${ }^{1} \mathrm{H},{ }^{13} \mathrm{C}, \mathrm{HSQC}$, and HMBC NMR spectra of compound $3 \mathbf{a}$ in $\mathrm{CDCl}_{3}$, Figures $\mathrm{S} 5-8:{ }^{1} \mathrm{H},{ }^{13} \mathrm{C}, \mathrm{HSQC}$, and HMBC NMR spectra of compound $\mathbf{3 b}$ in $\mathrm{CDCl}_{3}$, Figures S9-12: ${ }^{1} \mathrm{H},{ }^{13} \mathrm{C}$, HSQC, and HMBC NMR spectra of compound $3 \mathrm{c}$ in $\mathrm{CDCl}_{3}$, Figures S13-16: ${ }^{1} \mathrm{H}$, ${ }^{13} \mathrm{C}$, HSQC, and HMBC NMR spectra of compound $3 \mathbf{d}$ in $\mathrm{CDCl}_{3}$, Figures S17-20: ${ }^{1} \mathrm{H},{ }^{13} \mathrm{C}, \mathrm{HSQC}$, and HMBC NMR spectra of compound $3 \mathrm{f}$ in $\mathrm{CDCl}_{3}$.

Acknowledgments: Support from CONICET, ANPCyT and Universidad Nacional de Rosario from Argentina (UNR) is gratefully acknowledged.

Author Contributions: Mirta P. Mischne and Ernesto G. Mata conceived and designed the experiments; Agustina La-Venia performed the experiments and analyzed the data; Agustina La-Venia, Mirta P. Mischne, and Ernesto G. Mata wrote the paper.

Conflicts of Interest: The authors declare no conflict of interest. The funding sponsors had no role in the design of the study; in the collection, analyses, or interpretation of data; in the writing of the manuscript, and in the decision to publish the results.

\section{References}

1. Arcadi, A. Alternative Synthetic Methods through New Developments in Catalysis by Gold. Chem. Rev. 2008, 108, 3266-3325. [CrossRef] [PubMed]

2. Furstner, A.; Davies, P.W. Catalytic Carbophilic Activation: Catalysis by Platinum and Gold pi-Acids. Angew. Chem. Int. Ed. 2007, 46, 3410-3449. [CrossRef] [PubMed]

3. Furstner, A. Gold and platinum catalysis-a convenient tool for generating molecular complexity. Chem. Soc. Rev. 2009, 38, 3208-3221. [CrossRef] [PubMed]

4. Hashmi, A.S.; Rudolph, M. Gold catalysis in total synthesis. Chem. Soc. Rev. 2008, 37, 1766-1775. [CrossRef] [PubMed]

5. Rudolph, M.; Hashmi, A.S. Gold catalysis in total synthesis-an update. Chem. Soc. Rev. 2012, 41, 2448-2462. [CrossRef] [PubMed]

6. Shen, H.C. Recent advances in syntheses of heterocycles and carbocycles via homogeneous gold catalysis. Part 1: Heteroatom addition and hydroarylation reactions of alkynes, allenes, and alkenes. Tetrahedron 2008, 64, 3885-3903. [CrossRef] 
7. Shen, H.C. Recent advances in syntheses of carbocycles and heterocycles via homogeneous gold catalysis. Part 2: Cyclizations and cycloadditions. Tetrahedron 2008, 64, 7847-7870. [CrossRef]

8. Gorin, D.J.; Sherry, B.D.; Toste, F.D. Ligand Effects in Homogeneous Au Catalysis. Chem. Rev. 2008, 108, 3351-3378. [CrossRef] [PubMed]

9. Pflasterer, D.; Hashmi, A.S. Gold catalysis in total synthesis - recent achievements. Chem. Soc. Rev. 2016, 45, 1331-1367. [CrossRef] [PubMed]

10. Shahzad, S.A.; Sajid, M.A.; Khan, Z.A.; Canseco-Gonzalez, D. Gold catalysis in organic transformations: A review. Synth. Commun. 2017, 47, 735-755. [CrossRef]

11. Echavarren, A.M.; Hashmi, A.S.; Toste, F.D. Gold Catalysis-Steadily Increasing in Importance. Adv. Synth. Catal. 2016, 358, 1347. [CrossRef]

12. Dyker, G. An Eldorado for Homogeneous Catalysis? Angew. Chem. Int. Ed. 2000, 39, 4237-4239. [CrossRef]

13. Hashmi, A.S. Gold-Catalyzed Organic Reactions. Chem. Rev. 2007, 107, 3180-3211. [CrossRef] [PubMed]

14. Hashmi, A.S. Homogeneous Gold Catalysis Beyond Assumptions and Proposals-Characterized Intermediates. Angew. Chem. Int. Ed. 2010, 49, 5232-5241. [CrossRef] [PubMed]

15. Hashmi, A.S. Dual Gold Catalysis. Acc. Chem. Res. 2014, 47, 864-876. [CrossRef] [PubMed]

16. Huang, H.; Zhou, Y.; Liu, H. Recent advances in the gold-catalyzed additions to C-C multiple bonds. Beilstein J. Organ. Chem. 2011, 7, 897-936. [CrossRef] [PubMed]

17. Li, Z.; Brouwer, C.; He, C. Gold-Catalyzed Organic Transformations. Chem. Rev. 2008, 108, 3239-3265. [CrossRef] [PubMed]

18. Skouta, R.; Li, C.J. Gold-catalyzed reactions of C-H bonds. Tetrahedron 2008, 64, 4917-4938. [CrossRef]

19. Gorin, D.J.; Toste, F.D. Relativistic effects in homogeneous gold catalysis. Nature 2007, 446, $395-403$. [CrossRef] [PubMed]

20. Corma, A.; Leyva-Perez, A.; Sabater, M.J. Gold-Catalyzed Carbon-Heteroatom Bond-Forming Reactions. Chem. Rev. 2011, 111, 1657-1712. [CrossRef] [PubMed]

21. Hashmi, A.S. Homogeneous gold catalysts and alkynes: A successful liaison. Gold Bull. 2003, 36, 3-9. [CrossRef]

22. Jimenez-Nunez, E.; Echavarren, A.M. Molecular diversity through gold catalysis with alkynes. Chem. Commun. 2007, 43, 333-346. [CrossRef] [PubMed]

23. Jimenez-Nuñez, E.; Echavarren, A.M. Gold-Catalyzed Cycloisomerizations of Enynes: A Mechanistic Perspective. Chem. Rev. 2008, 108, 3326-3350. [CrossRef] [PubMed]

24. Kennedy-Smith, J.J.; Staben, S.T.; Toste, F.D. Gold(I)-Catalyzed Conia-Ene Reaction of beta-Ketoesters with Alkynes. J. Am. Chem. Soc. 2004, 126, 4526-4527. [CrossRef] [PubMed]

25. Muzart, J. Gold-catalysed reactions of alcohols: Isomerisation, inter- and intramolecular reactions leading to C-C and C-heteroatom bonds. Tetrahedron 2008, 64, 5815-5849. [CrossRef]

26. Dorel, R.; Echavarren, A.M. Gold(I)-Catalyzed Activation of Alkynes for the Construction of Molecular Complexity. Chem. Rev. 2015, 115, 9028-9072. [CrossRef] [PubMed]

27. Chiarucci, M.; Bandini, M. New developments in gold-catalyzed manipulation of inactivated alkenes. Beilstein J. Organ. Chem. 2013, 9, 2586-2614. [CrossRef] [PubMed]

28. Zhu, Y.; Zhou, W.; Petryna, E.M.; Rogers, B.R.; Day, C.S.; Jones, A.C. Insights into Alkene Activation by Gold: Nucleophile Activation with Base as a Trigger for Generation of Lewis Acidic Gold. ACS Catal. 2016, 6, 7357-7362. [CrossRef]

29. Bay, S.; Englert, A.; Nalivela, K.S.; Hashmi, A.S.; Larsen, M.H. Gold catalysis: Experimental mechanistic insights into the anellation of phenols with 1,3-dienes. J. Organomet. Chem. 2015, 795, 58-62. [CrossRef]

30. Hashmi, A.S.; Ramamurthi, T.D.; Rominger, F. Synthesis, structure and reactivity of organogold compounds of relevance to homogeneous gold catalysis. J. Organomet. Chem. 2009, 694, 592-597. [CrossRef]

31. Klatt, G.; Xu, R.; Pernpointner, M.; Molinari, L.; Quang-Hung, T.; Rominger, F.; Hashmi, A.S.; Koppel, H. Are beta-H-Eliminations or Alkene Insertions Feasible Elementary Steps in Catalytic Cycles Involving Gold(I) Alkyl Species or Gold(I) Hydrides? Chem. A Eur. J. 2013, 19, 3954-3961. [CrossRef] [PubMed]

32. Bandini, M.; Monari, M.; Romaniello, A.; Tragni, M. Gold-Catalyzed Direct Activation of Allylic Alcohols in the Stereoselective Synthesis of Functionalized 2-Vinyl-Morpholines. Chem. A Eur. J. 2010, 16, 14272-14277. [CrossRef] [PubMed] 
33. Han, X.; Widenhoefer, R.A. Gold(I)-Catalyzed Intramolecular Hydroamination of Alkenyl Carbamates. Angew. Chem. Int. Ed. 2006, 45, 1747-1749. [CrossRef] [PubMed]

34. Hirai, T.; Hamasaki, A.; Nakamura, A.; Tokunaga, M. Enhancement of Reaction Efficiency by Functionalized Alcohols on Gold(I)-Catalyzed Intermolecular Hydroalkoxylation of Unactivated Olefins. Org. Lett. 2009, 11, 5510-5513. [CrossRef] [PubMed]

35. Iglesias, A.; Muñiz, K. Oxidative Interception of the Hydroamination Pathway: A Gold-Catalyzed Diamination of Alkenes. Chem. A Eur. J. 2009, 15, 10563-10569. [CrossRef] [PubMed]

36. Yang, C.G.; He, C. Gold(I)-Catalyzed Intermolecular Addition of Phenols and Carboxylic Acids to Olefins. J. Am. Chem. Soc. 2005, 127, 6966-6967. [CrossRef] [PubMed]

37. Zhang, G.; Cui, L.; Wang, Y.; Zhang, L. Homogeneous Gold-Catalyzed Oxidative Carboheterofunctionalization of Alkenes. J. Am. Chem. Soc. 2010, 132, 1474-1475. [CrossRef] [PubMed]

38. Zhang, J.; Yang, C.G.; He, C. Gold(I)-Catalyzed Intra- and Intermolecular Hydroamination of Unactivated Olefins. J. Am. Chem. Soc. 2006, 128, 1798-1799. [CrossRef] [PubMed]

39. Denes, F.; Perez-Luna, A.; Chemla, F. Addition of Metal Enolate Derivatives to Unactivated Carbon-Carbon Multiple Bonds. Chem. Rev. 2010, 110, 2366-2447. [CrossRef] [PubMed]

40. Fang, W.; Presset, M.; Guerinot, A.; Bour, C.; Bezzenine-Lafollee, S.; Gandon, V. Cationic gold(I)-catalyzed enantioselective hydroalkylation of unactivated alkenes: Influence of the chloride scavenger on the stereoselectivity. Org. Chem. Front. 2014, 1, 608-613. [CrossRef]

41. Porcel, S.; López-Carrillo, V.; García-Yebra, C.; Echavarren, A.M. Gold-Catalyzed Allyl-Allyl Coupling. Angew. Chem. Int. Ed. 2008, 47, 1883-1886. [CrossRef] [PubMed]

42. Xiao, Y.P.; Liu, X.Y.; Che, C.M. Efficient Gold(I)-Catalyzed Direct Intramolecular Hydroalkylation of Unactivated Alkenes with alpha-Ketones. Angew. Chem. Int. Ed. 2011, 50, 4937-4941. [CrossRef] [PubMed]

43. Nguyen, R.V.; Yao, X.Q.; Bohle, D.S.; Li, C.J. Gold- and Silver-Catalyzed Highly Regioselective Addition of Active Methylenes to Dienes, Triene, and Cyclic Enol Ethers. Org. Lett. 2005, 7, 673-675. [CrossRef] [PubMed]

44. Vayer, M.; Fang, W.; Guillot, R.; Bezzenine-Lafollee, S.; Bour, C.; Gandon, V. Acid-catalysed intramolecular addition of beta-ketoesters to 1,3-dienes. Org. Biomol. Chem. 2017, 15, 584-588. [CrossRef] [PubMed]

45. Yao, X.; Li, C.J. Highly Efficient Addition of Activated Methylene Compounds to Alkenes Catalyzed by Gold and Silver. J. Am. Chem. Soc. 2004, 126, 6884-6885. [CrossRef] [PubMed]

46. Zhou, C.Y.; Che, C.M. Highly Efficient Au(I)-Catalyzed Intramolecular Addition of beta-Ketoamide to Unactivated Alkenes. J. Am. Chem. Soc. 2007, 129, 5828-5829. [CrossRef] [PubMed]

47. Balamurugan, R.; Koppolu, S.R. Scope of AuCl3 in the activation of per-O-acetylglycals. Tetrahedron 2009, 65, 8139-8142. [CrossRef]

48. Fang, W.; Presset, M.; Guerinot, A.; Bour, C.; Bezzenine-Lafollee, S.; Gandon, V. Silver-Free Two-Component Approach in Gold Catalysis: Activation of [LAuCl] Complexes with Derivatives of Copper, Zinc, Indium, Bismuth, and Other Lewis Acids. Chem. Eur. J. 2014, 20, 5439-5446. [CrossRef] [PubMed]

49. Guerinot, A.; Fang, W.; Sircoglou, M.; Bour, C.; Bezzenine-Lafollee, S.; Gandon, V. Copper Salts as Additives in Gold(I)-Catalyzed Reactions. Angew. Chem. Int. Ed. 2013, 52, 5848-5852. [CrossRef] [PubMed]

50. Nguyen, R.V.; Li, C.J. An Annulation toward Fused Bicyclolactones. J. Am. Chem. Soc. 2005, 127, $17184-17185$. [CrossRef] [PubMed]

51. Jagdale, A.R.; Youn, S.W. AuI-Catalyzed Intramolecular Cyclization of 2-Alkenylphenyl Carbonyl Compounds: Exploring the Oxophilic Lewis Acidity of AuI Species. Eur. J. Org. Chem. 2011, 2011, 3904-3910. [CrossRef]

52. Zhang, X.; Corma, A. Effective Au(III)-CuCl2-catalyzed addition of alcohols to alkenes. Chem. Commun. 2007, 43, 3080-3082. [CrossRef] [PubMed]

53. Rosenfeld, D.C.; Shekhar, S.; Takemiya, A.; Utsunomiya, M.; Hartwig, J.F. Hydroamination and Hydroalkoxylation Catalyzed by Triflic Acid. Parallels to Reactions Initiated with Metal Triflates. Org. Lett. 2006, 8, 4179-4182. [CrossRef] [PubMed]

54. Hashmi, A.S.; Schafer, S.; Goker, V.; Eisenbach, C.D.; Dirnberger, K.; Zhao-Karger, Z.; Crewdson, P. Gold Catalysis: AuCl-induced Polymerization of Styrene and n-Butylvinylether. Aust. J. Chem. 2014, 67, 500-506. [CrossRef] 
55. Urbano, J.; Hormigo, A.J.; de Fremont, P.; Nolan, S.P.; Diaz-Requejo, M.M.; Perez, P.J. Gold-promoted styrene polymerization. Chem. Commun. 2008, 759-761. [CrossRef]

56. Hashmi, A.S.; Frost, T.M.; Bats, J.W. Highly Selective Gold-Catalyzed Arene Synthesis. J. Am. Chem. Soc. 2000, 122, 11553-11554. [CrossRef]

57. Hashmi, A.S.; Schwarz, L.; Choi, J.H.; Frost, T.M. A New Gold-Catalyzed C-C Bond Formation. Angezw. Chem. Int. Ed. 2000, 39, 2285-2288. [CrossRef]

58. Reichardt, C.; Welton, T. Solvents and Solvent Effects in Organic Chemistry, 4th ed.; Wiley-VCH Verlag \& Co. KGaA: Weinheim, Germany, 2011; ISBN 978-3-527-32473-6.

Sample Availability: Samples of the compounds are available from the authors.

(C) 2018 by the authors. Licensee MDPI, Basel, Switzerland. This article is an open access article distributed under the terms and conditions of the Creative Commons Attribution (CC BY) license (http:// creativecommons.org/licenses/by/4.0/). 